\title{
Peran Sarana Angkutan Darat Dalam Upaya Peningkatan Efisiensi Distribusi Ternak Dan Hasil Ternak Sapi Potong Di Indonesia
}

\section{Means of Land Transport role In Improving Efficiency Distribution of Livestock and Cattle Product In Indonesia}

\section{Bambang Winarso}

Pusat Sosial Ekonomi dan Kebijakan Pertanian, Badan Litbang Pertanian, Bogor.

\begin{abstract}
In livestock trading system and cattle product such as meat and other livestock products always involves some businesses that make up the chain of marketing. Tradable commodity that can be distributed right from the producer to the end consumer in the form of live cattle or in the form of livestock product. Distribution activities of livestock and livestock products by land necessarily involves a good means of land transport trains, trucks and other means of land transport. While also involving the various levels of the marketing chain of middlemen village level, large padagang up with retailers. Implementation of the distribution chain between marketing is not just a process of transporting goods. Consistent with the mechanism of the existing business, there will be a new price formation on each node chain path. The longer the chain through which the formation of prices will be higher. Such conditions led to the emergence of the marketing margin distribution on each node marketing chain. The amount of the marketing margin generated between the node is varied, it is largely determined by many things, in addition to the cost of marketing, also the advantage taken by the perpetrator. The study was conducted in East Java and West Java in 2013. Analysis of data using simple cross-tabulation of data derived from primary data and secondary data
\end{abstract}

Keywords: Land Transport, Distribution and Livestock

Diterima disetujui

\section{PENDAHULUAN}

Indonesia yang merupakan negara kepulauan, angkutan ternak dari sentra produksi ke sentra konsumsi menggunakan lebih dari satu moda transportasi. Pola yang demikian merupakan pola multi moda. Angkutan multimoda didalam Peraturan Pemerintah No 8 Tahun 2011 tentang agkutan multimoda yang didefinisikan bahwa angkutan multimoda adalah angkutan barang dengan menggunakan paling sedikit 2 (dua) moda angkutan yang berbeda atas dasar 1 (satu) kontrak sebagai dokumen angkutan multimoda dari satu tempat diterimanya barang oleh badan usaha angkutan multimoda ke suatu tempat yang ditentukan untuk penyerahan barang kepada penerima barang angkutan multimoda. 
Bambang Winarso: Peran Sarana Angkutan Darat Dalam Upaya Peningkatan Efisiensi Distribusi Ternak ...

Transportasi darat saat ini memegang peranan yang sangat penting. Jenis angkutan darat meliputi jalan dan angkutan jalan raya, angkutan dalam kota, serta angkutan sungai, danau dan feri. Alat angkutan darat ini memiliki fungsi yang saling melengkapi, sehingga dalam pengembangannya perlu direncanakan secara terintegrasi. Dalam Undang-Undang Nomor 38 Tahun 2004 Pasal 5 disebutkan bahwa jalan memiliki fungsi Sebagai berikut : (Jurnal Kajian Lemhannas RI Edisi 14, 2012) (1) sebagai bagian dari prasarana transportasi yang mempunyai peran penting dalam ekonomi, sosial budaya, politik, pertahanan dan keamanan, lingkungan hidup serta wajib dipergunakan untuk sebesar-besarnya kemakmuran rakyat; (2) sebagai prasarana distribusi barang dan jasa yang merupakan urat nadi kehidupan masyarakat, bangsa dan negara; (3) sebagai satu kesatuan sistem jaringan jalan yang mengikat seluruh wilayah Republik Indonesia.

Undang-Undang No. 14 Tahun 1992 tentang Lalu Lintas dan Angkutan Jalan menyebutkan bahwa peraturan yang mengatur angkutan jalan raya dapat dibagi menjadi dua jenis: peraturan yang berkaitan dengan kegiatan operasional perusahaan angkutan truk, kendaraan, dan penggunaan jalan; serta peraturan yang terkait dengan sarana dan prasarana fisik. Kedua jenis peraturan ini terkait dengan peraturan tingkat pusat tentang standar keselamatan dan teknis, yang bertujuan untuk menjaga keselamatan di jalan maupun mutu jalan-jalan umum (The Asia Foundation, 2008).

Efisiensi moda transportasi tidak hanya menyangkut aspek biaya secara langsung tetapi juga kerugian secara tidak langsung. Transportasi yang buruk dapat memiliki efek serius pada kesejahteraan ternak dan dapat menyebabkan kerugian yang signifikan dari kualitas dan produksi (Chambers and Grandin, 2001). Untuk kasus Indonesia, konsumen belum banyak melihat aspek, namun penurunan produksi berupa penyusutan berat badan berdampak pada biaya dan mempengaruhi harga. Penurunan berat badan dan kualitas daging pada ternak sapi selama transportasi dapat disebabkan oleh: (i) ternak ketakutan dan kesakitan yang menyebabkan stres, (ii) kembung lambung akibat sapi berada pada posisi terikat sehingga tidak leluasa bergerak, (iii) dehidrasi pada perjalanan jarak jauh tanpa penyiraman yang tepat akan menurunkan berat badan dan bisa mati, dan (iv) kelelahan.

Ilham dan Yusdja (2004) menyatakan bahwa sarana transportasi ternak menggunakan transportasi darat yaitu truk dan kereta api serta transportasi laut. Selama transportasi dari Jawa Timur dan Jawa Tengah menuju Jawa Barat dan DKI Jakarta ternak sapi yang diangkut mengalami susut berat badan sekitar 5\% dan untuk tenak sapi yang diangkut dari luar Jawa (NTT dan NTB) dengan tujuan yang sama mengalami susut sekitar 10,5\%. Angkutan ternak dari NTT dan NTB ke sentra konsumsi Jawa Barat dan DKI menggunakan multi moda transportasi. Dari peternak ke pasar hewan hingga masuk karantina di pelabuhan menggunakan angkutan truk. Kemudian dari pelabuhan Tenau di Kupang-NTT dan pelabuhan Lembar-NTB menuju pelabuhan Kalimas Surabaya menggunakan angkutan laut, dilanjutkan lagi dengan menggunakan truk menuju Jawa Barat dan DKI Jakarta. Untuk daerah tertentu seperti Sumatera - Jawa dan Sulawesi Selatan - Kalimantan Timur angkutan truk didukung oleh angkutan penyeberangan berupa kapal ferri tanpa melalui proses bongkar muat.

Biaya transportasi dipengaruhi oleh ketersediaan dan efisiensi moda transportasi yang digunakan. Menurut Abubakar (2011), moda transportasi merupakan istilah yang digunakan untuk menyatakan alat angkut yang digunakan untuk berpindah tempat dari satu tempat ketempat lain. Ragam moda transportasi dapat dikelompokkan atas moda yang ber jalan didarat, berlayar di perairan laut dan pedalaman serta moda yang terbang di udara. Moda yang didarat juga masih bisa dikelompokkan atas moda jalan, moda kereta api dan moda pipa.

Beberapa kelebihan menggunakan jasa tansportasi kereta api adalah: (1) risiko kecelakaan yang terjadi menjadi tanggungan perusahaan angkutan kereta api, (2) selama perjalanan tidak ada 
pungutan baik resmi maupun tidak resmi, (3) ongkos relatif murah jika dibandingkan dengan menggunakan truk (Ilham dan Yusdja, 2004). Namun saat ini angkutan kereta api tidak lagi digunakan untuk mengangkut ternak sapi. Menurut PT. KAI saat itu, usaha angkutan ternak sapi sudah tidak layak secara ekonomi karena gerbong yang digunakan dari Jawa Timur Ke Jawa Barat untuk nagkut sapi, kembali ke Jawa Timur dalam keadaan kosong. Di waktu sebelumnya muatan dari Barat ke Timur berisi besi baja dari Cilegon yang menyebabkan gerbong cepat rusak.

Secara metodologis penelitian ini merupakan bagian dari hasil penelitian tentang "Kajian Efisiensi Moda Transportasi Ternak dan Daging Sapi Dalam Mendukung Program Swasembada Daging Sapi” yang dilakukan oleh Pusat Sosial Ekonomi dan Kebijakan Pertanian, Badan Litbang Pertanian, thn 2013. Lokasi penelitian untuk kasus transportasi darat lebih di tekankan pada wilayah Pulau Jawa khususnya Jawa Timur dan Jawa Barat serta DKI Jakarta. Adapun responden utama adalah pelaku usaha dibidang transportasi khususnya transportasi darat yang erat kaitannya dengan distribusi ternak dan hasil ternak baik perusahaan maupun perorangan.

\section{HASIL DAN PEMBAHASAN}

Transportasi adalah kegiatan pemindahan barang (muatan) dan penumpang dari suatu tempat ke tempat lain. Menurut Abubakar (2011), moda transportasi merupakan istilah yang digunakan untuk menyatakan alat angkut yang digunakan untuk berpindah tempat dari satu tempat ketempat lain. Ragam moda transportasi dapat dikelompokkan atas moda yang ber jalan didarat, berlayar di perairan laut dan pedalaman serta moda yang terbang di udara. Dalam makalah ini lebih ditekankan pada masalah transportasi melalui jalan darat, dengan alasan bahwa untuk kasus transporatsi ternak dn hasil ternak di Pulau Jawa, sarana ini lebih dominan digunakan dari pada lewat jalan laut maupun udara.

\section{Transportasi Darat}

Moda transportasi darat dapat dikelompokkan atas tiga moda yaitu moda jalan, moda melalui rel kereta api dan moda lewat pipa. Keberadaan sarana transportasi dimaksudkan agar kegiatan distribusi bisa dilakukan secara lancar juga bisa lebih efisien. Efisiensi transportasi adalah suatu ukuran besarnya biaya (dalam rupiah, waktu, energi atau tambahan lainnya) untuk menggerakkan sesuatu barang (dalam hal ini ternak dan hasil ternak sapi) dari satu tempat ke tempat lain (Wikipedia, 2011). Sementara Abbas, 2006 menjelaskan bahwa transportasi memiliki lima unsur pokok yang saling berkaitan, yang pertama 'Manusia', sebagai yang membutuhkan transportasi, salain itu ada 'barang', sebagai kebutuhan manusia yang akan di pindahkan selain manusia itu sendiri, selanjutnya 'kendaraan', sebagai sarana atau alat yang digunakan. Selanjutnya 'jalan', sebagai prasarana transportasi, serta 'organisasi', sebagai pengelola transportasi.

Dilihat dari kebutuhan transportasi menunjukkan bahwa kegiatan distribusi barang dari tempat yang satu ketempat yang lain mutlak membutuhkan sara angkut manakala barang yang diangkut tersebut melebihi kemampuan tenaga angkut manusia. Keterbatasan tenaga manusia disamping dihadapkan pada volume barang yang akan diangkut juga dihadapkan pada kendala lain yaitu jarak yang akan ditempuh, kebutuhan waktu angkut yang diperlukan serta keamanan barang yang akan diangkut. Untuk itulah manusai membutuhkan sarana transportasi guna mengatasi segala keterbatasan tersebut diatas.

Sementara dilihat dari jenis barang yang akan diangkut dapat dapat dibedakan atas keadaan/jenis serta volume barang yang akan diangkut. Dilihat dari jenis barang yang akan diangkut, 
Bambang Winarso: Peran Sarana Angkutan Darat Dalam Upaya Peningkatan Efisiensi Distribusi Ternak ...

maka barang tersebut bisa dikategorikan barang padat,cair atau berupa gas. Dengan karakteristik tersebut maka sarana angkutan yang dibutuhkan disesuaikan dengan keadaan barang tersebut serta penanganannya juga berbeda-beda. Dalam kegiatan tranportasi barang maka kendaraan yang digunakan juga beragam. Keragaman jenis kendaraan yang digunakan tersebut disesuaikan dengan kondisi, volume serta sifat barang yang akan diangkut. Berdasarkan jenis kendaraan yang digunakan maka pengangkutan barang dapat dilakukan dengan menggunakan kereta api, kendaraan truk baik ukuran besar, sedang maupun ukuran kecil serta kendaraan khusus seperti truk tangki, mobil refrigerator dan kendaraan khusus lainnya.

Guna meningkatkan kelancaran distribusi barang, disamping menggunakan kendaraan juga dibutuhkan sarana jalan yang memadai. Jalan menurut kondisinya dapat dibedakan menjadi jalan aspal, jalan batu diperkeras maupun jalan tanah. Seangkan jalan menurut kelasnya dapat dibedakan menjadi jalan kelas satu atau jalan Negara, jalan kelas dua (jalan propinsi) dan jalan kelas tiga (jalan kabupaten). Keadaan jalan berdasarkan kelasnya tersebut tentu akan menentukan jenis kendaraan yang akan melaluinya. Satu hal penting dalam kegiatan transportasi adalah adanya organisasi yang menangani kegiatan tersebut. Kegiatan transportasi dalam skala tertentu tentu membutuhkan penanganan yang memadai. Untuk itu dibutuhkan sebuah organisasi yang dapat "memanage" kegiatan tersebut agar dapat berjalan sesuai dengan yang direncanakan. Ilham et al., 2013 dan Winarso, 2014 mengemukakan bahwa dalam upaya mendukung kegiatan distribusi ternak sapi potong dari daerah produsen ke daerah konsumen melalui jalan darat, penggunaan kendaraan roda empat atau lebih seperti truk sangat umum digunakan. Dan dalam sistem distribusi barang tersebut umumnya digunakan dua jenis angkutan darat utama yaitu kereta api dan truk.

\section{Kereta Api}

Kereta api merupakan sarana angkutan darat yang digunakan baik untuk mengangkut barang juga mengangkut manusia. Untuk menangani kegiatan angkutan dengan menggunakan jenis angkutan ini maka dalam operasionalnya ditangani oleh lembaga swasta milik pemerintah yaitu PT Kereta Api Indonesia (PT. KAI). PT KAI merupakan salah satu lembaga yang bergerak di bidang moda transportasi darat dalam kegiatan bisnisnya telah melakukan kerjasama binis dengan beberapa perusahaan yang membutuhkan jasa angkutan kereta api.

Berdasarkan informasi dilapangan menunjukkan bahwa bisnis yang saat ini ditempuh terutama adalah kereta api yang menempuh jalur lintas utara dan kereta api yang menempuh jalur lintas selatan. Selama ini disediakan dua rute utama yaitu rute utara Surabaya - Jakarta pp dan route jalur selatan Surabaya-Madiun-Solo-Yogyakarta-Purwokerto-Bandung pp. Adapun jalur utara yang dilalui oleh jasa angkutan ini adalah (Jakarta, Cirebon, Semarang, Surabaya pp). Selama satu bulan pihak PT. KAI setiap harinya menyediakan dua rangkaian kereta api masing-masing satu rangkaian dari Jakarta menuju Surabaya dan satu rangkaian dari Surabaya menuju Jakarta demikian juga jalur selatan. Dalam setiap satu rangkaian terdiri dari satu lokomotif dan 20 gerbong. Bahkan ke depan untuk jalur pantura jumlah gerbong akan ditingkatkan menjadi 30 unit.

Besaran biaya yang dikenakan dari Surabaya s/d Jakarta per TEUs (1 TEUs setara dengan 20 feet) Rp.1.600.000, jika dibandingkan dengan menggunakan angkutan truk Surabaya s/d Jakarta Rp. 3.400.000. Beberapa kelebihan sistem angkutan kereta api diantaranya adalah (a) harga lebih murah dibandingkan dengan sistim angkutan darat lainnya, (b) ketepatan waktu, angkutan barang dengan menggunakan kereta api dapat dikatakan tidak ada hambatan, (c) ditanggung bebas pungli selama di perjalanan dan (d) ketersediaan sarana dan prasarana yang bisa diandalkan. 
Dalam melaksanakan kegiatan operasionalnya, PT KAI bekerjasama dengan PT Buana, PT Jatim Petolium Transport dan PT KA Logistik, dimana PT KA logistic merupakan anak perusahaan dari PT KAI. Sistim kerjasama yang dilakukan adalah sistem B to B (bussines to bussines). PT KAI sendiri saat ini telah menetapkan target angkutannya sebesar 1500 TEUs/bulan. Setiap gerbong mampu mengangkut dua TEUs. Jika dibandingkan dengan menggunakan truk, biaya yang dikenakan PT.KAI diperkirakan hanya 75\%, 1 gerbong memuat 2 kontainer, 1 kontainer = 2,5 ton, 1 rangkaian kereta barang memuat barang kurang lebih sekitar 42 ton.

Untuk melayani jasa angkutan barang, pihak PT KAI telah memfokuskan pada infestasi gerbong datar type PPCW yaitu type gerbong datar yang multifungsi yang tidak tentu barang yang akan diangkut. Menurut rencana akan dibangun gerbong datar type PPCW sebanyak 3.000 unit, akan tetapi saat ini sudah tersedia gerbong yang sama sebanyak 1.200 unit. Dalam satu rangkaian kereta api, agar efisien maka jumlah yang ditarik oleh 1 lokomotif adalah sebanyak antara 16 s/d 20 gerbong barang. Dari hasil diskusi menunjukkan bahwa saat ini pihak PT KAI belum siap untuk melakukan pengengkutan ternak sapi hidup, disamping sarana angkutannya belum ada, juga hal ini akan bertentangan dengan kebijakan pihak PT KAI yang saat ini sedang melakukan pembenahan kebersihan dan ketertiban di setiap lingkungan stasiun KA.

Selama ini antara rangkaian gerbong barang dan penumpang memungkinkan untuk disatukan. Dimana posisi gerbong barang diletakkan pada urutan pertama dan terakhir. Rangkaian demikian disebut kereta aling-aling yang difungsikan sebagai barang hantaran potongan dan tetap bekerjasama dengan pihak ekspeditur. Semua jenis barang dapat diangkut kecuali B3 dan ternak. Diantara barang yang diangkut adalah semen, mebel, perabot rumah tangga, elektronik, motor, sparepart, material bangunan, dll. Sehingga kalaupun ada kerjasama pengengkutan, maka lebih kearah pengangkutan hasil ternak berupa daging beku dengan sistem river container.

Dalam merintis bisnis angkutan barang (daging beku), maka ada 3 opsi yang sedang dibangun oleh pihak PT KAI yaitu : (a) dari pihak pengusaha ternak agar menghubungi ekpeditur eksisting, (b) pihak pengusaha ternak dapat bekerja dengan/secara grouping (perserikatan) dengan para pedagang daging, (c) pengusaha ternak dapat memilih ekpeditur lain yang belum bekerjasama dengan PT KAI. Hal ini perlu dilakukan sebab apabila ada kerjasama dalam bentuk container, maka pihak PT KAI perlu membangun sarana-sarana yang memenuhi persyaratan angkutan barang terutama persyaratan BHP (Barang Hantaran Potongan).

Dalam sistem pembayaran, ada beberapa persyaratan yang telah ditentukan oleh pihak PT KAI apabila ekspeditur mau bekerjasama dengan PT KAI yaitu: (a) sistem pembayaran di depan, (b) sistem pembayaran saat keberangkatan barang yang diangkut dan (c) pembayaran dilakukan di belakang setelah barang diangkut. Sementara dasar penentuan besarnya biaya angkutan yang menggunakan jasa kereta api bahwa biaya operasi semua kereta api telah didasarkan pada ketentuan Peraturan Menteri Perhubungan dan Menteri Keuangan yaitu : (a) ton/km, (b) Teus/OD (Order Distination) dan (c) ton/OD. Ketentuan dari pihak PT KAI sendiri bahwa stand formasi setiap rangkaian adalah $16 \mathrm{~s} / \mathrm{d} 17$ gerbong/rangkaian.

Bagi pihak ekspeditur yang dapat memanfaatkan angkutan sebesar antara $1.500 \mathrm{~s} / \mathrm{d} 1.800$ maka biaya ongkos angkutan yang diberikan oleh pihak PT KAI adalah separoh harga, sedangkan $>1.800$ TEUs berlaku harga penuh (Full cost). Menurut informasi bahwa biaya angkutan dari Surabaya ke Jakarta adalah sebesar 1,56 juta/TEUs (sebagai catatan 1 truck > 1,56 juta). Untuk transaksi satu kontrak diperkirakan nilainya 1500 TEUs dikalikan Rp 1,6 juta yaitu Rp 2,4 miliar. Harga tersebut sebenarnya masih berpeluang dinegosiasikan. Faktor yang mempengaruhi ongkos tersebut diantaranya jenis barang yang diangkut, besar kecilnya perusahaan, dan kinerja usaha. Untuk angkutan barang, PT. 
Bambang Winarso: Peran Sarana Angkutan Darat Dalam Upaya Peningkatan Efisiensi Distribusi Ternak ...

KAI tidak memberlakukan subsidi melalui PSO (Public Service Obligation). Subsidi tersebut hanya digunakan untuk angkutan kereta penumpang. Namun peluang itu mungkin saja dilakukan.

Persyaratan kerjasama angkutan barang dengan PT. Kereta Api Indonesia dengan pihak ekspeditur adalah mengajukan Surat Permohonan Kerjasama dengan mencantumkan (a) Akta pendirian perusahaan. (b) Pengesahan akta pendirian perseroan terbatas oleh Menteri Hukum dan Ham RI (khusus untuk PT). (c) Surat Ijin Pengusahaan (SIUP). (d) Surat Keterangan Domisili Perusahaan (SKDP). (e) NPWP Perusahaan. (f) Alamat, nomor telepon dan fax perusahaan. (g) Laporan keuangan perusahaan selama dua tahun terakhir. (h) Company profile perusahaan dan (i) Bisnis plan kerjaama angkutan lima tahun ke depan.

Ada tiga kota yang memiliki stasiun container yaitu Jakarta, Bandung dan Surabaya. Pada setiap stasiun dilengkapi containeryard dan crane. Fasilitas stasiun container yang disediakan oleh pihak PT KAI yang berada di Surabaya diantaranya di Stasiun Kalimas, Pasarturi, Benteng dan Stasiun Waru. Sedangkan di Jakarta tersedia di Stasiun Gudang, Sungai Lapo, Pasoso dan Stasiun Cigading, sementara di Bandung tersedia di Stasiun Gedebage. Menurut informasi bahwa PT KA Logistik telah melakukan usahanya dengan menggunakan sistem operasi door to door maupun door to station dengan sistem jemput bola.

Dalam hal persaingan dalam sistem angkutan barang lewat darat saat ini PT KAI menghadapi saingan utamanya dengan pengusaha truk container. Saat ini masih banyak container yang diangkut menggunakan truk. Hal itu dapat terjadi karena angkutan kereta api menggunakan system kontrak dengan target partai besar. Masih banyak container partai kecil yang harus menggunakan jasa truk. Ke depan, PT. KAI melalui PT. Kereta api logistic akan mengembangkan angkutan multimoda. Untuk merealisasikan angkutan ternak pihak PT. KAI harus juga mempertimbangkan aspek estetika. Saat ini ihak PT. KAI selalu meningkatkan aspek kebersihan stasiun. Perlu dilakukan penyediaan khusus stasiun muat dan bongkar dan pemberhentian di perjalanan agar tidak mengganggu kenyamanan penumpang dan merusak estetika.

\section{Transportasi Truk}

Dalam upaya mendukung kegiatan distribusi ternak dan hasil ternak sapi potong dari daerah produsen ke daerah konsumen salah satunya adalah menggunakan truk. Penggunaan sarana angkutan truk umumnya ada dua cara yaitu menggunakan kendaraan milik sendiri atau sewa. Untuk angkutan jarak jauh lebih didominasi oleh kendaraan angkut model truk-truk ukuran besar maupun sedang. Sementara untuk jarak pendek dan skala yang diangkut tidak terlalu banyak, alat angkut yang digunakan biasanya menggunakan kendaraan kecil bak terbuka.

Dari hasil pengamatan lapangan, sistem sewa tampaknya lebih dominan, dengan alasan lebih praktis tampaknya merupakan latar belakang yang mendasari mengapa banyak pelaku bisnis ternak lebih senang menyewa kendaraan untuk melakukan pengiriman ternak ke pembeli. Kepraktisan tersebut cukup beralasan, mengingat bahwa dalam sistem sewa maka segala pengeluaran biaya yang terjadi di perjalanan selama dalam pengiriman ternak sudah ditanggung oleh pemilik kendaraan. Truk merupakan sarana transportasi darat yang saat ini paling banyak digunakan sebagai alat pengangkut ternak sapi potong. Disamping sarana ini mampu melayani semua jalur lintas ternak sapi potong, maka sarana angkutan tersebut disamping tidak terlalu sulit untuk mendapatkannya, maka ongkos sewanya juga terjangkau. Kemudahan proses sewa-menyewa serta kemudahan untuk mendapatkan sarana angkutan yang layak, aman dan terjangkau merupakan pilihan bagi banyak pengguna jasa angkutan darat. (Winarso, 2014). 
Truk merupakan sarana transportasi darat yang saat ini paling banyak digunakan sebagai alat pengangkut ternak sapi potong. Disamping sarana ini mampu melayani semua jalur lintas ternak sapi potong, maka sarana angkutan tersebut disamping banyak terdapat di semua tempat, maka ongkos sewanya juga terjangkau. Kemudahan untuk proses sewa-menyewa serta kemudahan untuk mendapatkan sarana angkutan yang layak, aman dan terjangkau merupakan pilihan bagi banyak pengguna jasa angkutan darat. Ada beberapa macam biaya yang harus dikeluarkan selama proses pengangkutan ternak dari penjual ternak ke pembeli ternak sapi potong baik biaya yang resmi dikeluarkan untuk biaya maupun biaya yang tidak resmi. Selain kebutuhan pokok bahan bakar (bensin/solar) maka ada beberapa macam biaya yang harus dikeluarkan diantaranya adalah biaya untuk memasuki jalan tol, biaya untuk akomodasi supir dan kenek, biaya pemeriksaan ternak di pos pemeriksaan ternak, biaya tak resmi (pungli) dan biaya operasional tahunan kendaraan seperti servis, ganti oli, ganti ban, pajak kendaraan maupun biaya penyusutan kendaraan. Belum lagi resiko kendaraan rusak, kecelakaan dan resiko lainnya. Hal yang demikian menyebabkan para pengirim ternak lebih banyak memilih menyewa kendaraan. Akan tetapi ada sebagian pelaku bisnis yang dalam melakukan pengiriman ternak menggunakan kendaraan sendiri, hal ini lebih dilatar belakangi adanya efisiensi biaya transportasi.

Pengangkutan ternak dari Jawa Tengah/Jawa Timur ke Jawa Barat banyak menggunakan sistem sewa. Beberapa kasus menunjukkan bahwa salah satu responden dalam sistem transportasi yang digunakan untuk mengangkut ternak sapi potong dari Oku Timur (Sumatera Selatan) ke Pasar Ciwareng-Purwakarta menggunakan kendaraan truk dengan system sewa. Jangka waktu yang dibutuhkan sekitar 19 jam, berangkat dari Oku Timur jam 15.00 sore tiba di Bakahuni jam 2.00 malam (sapi istirahat sekitar 2 jam) dan tiba di Pasar Ciwareng jam 10 pagi dan sapi diistirahatkan sambil menunggu pembeli dan hari pasaran ternak. Besarnya biaya yang dikeluarkan untuk mengangkut sapi dari Oku Timur ke Purwakarta sekitar Rp 6,0 juta/truk (isi biasanya 15-18 ekor) dengan perincian : Rp 2,0 juta sewa mobil, Rp 4,0 juta untuk sopir dan kenek diantaranya untuk biaya mengurus surat-surat (Disnak Rp 50.000,-, Polsek Rp 50.000,-, Kelurahan Rp 20,000, Pelabuhan Bakahuni Rp 25.000 agar didulukan, sewa kandang Rp 350.000/hari (termasuk makan minum ternak) dan biaya bahan bakar. Sementara bagi ternak yang laku terjual dibutuhkan biaya urat pengeluaran ternak sebesar $\mathrm{Rp}$ 8000/ekor. Pembeli umumnya merupakan sesama pedagang atau bisa peternak langsung.

Kasus pengiriman ternak sapi potong lainnya yaitu dari Banyuwangi ke Sukabumi maka dalam pengiriman ternak sapi ke RPH Bojongkokosan (Sukabumi), maka jalur yang ditempuh adalah : Banyuwangi - Situbondo - Probolinggo - Surabaya - Lamongan - Bojonegoro - Cepu - Purwodadi Semarang - Tulis/Pekalongan (ternak istirahat) - Cirebon - Krawang - Jagorawi - Bogor - Ciawi Bojongkokosan. Berangkat dari Banyuwangi jam 3.00 pagi, tiba di Tulis jam 2.00 pagi dan istirahat 4 jam. Berangkat dari Tulis jam 6.00 pagi tiba di Bojongkokosan jam 18.00 sore, sapi istirahat sehari semalam sebelum di potong. Biaya sewa kendaraan adalah sebesar Rp 3.200.000, biaya tersebut diperuntukkan untuk biaya bahan bakar, biaya tol, biaya polisi dan akomodasi sopir dan kenek), biaya pos pemeriksaan ternak di Situbondo, Pos ternak di Padangan-Bojonegoro, pos ternak di TanjungBrebes, Pos ternak di Losari-Cirebon, masing-masing pos Rp 10.000. Pengangkutan ternak terakhir sebanyak 14 ekor terdiri dari Sapi Bali 5 ekor, Sapi Simental 3 ekor, Sapi PO 1 ekor, Kerbau 1 ekor, sapi Limousin 4 ekor.

Sementara bagi pebisnis ternak sapi potong yang memiliki kendaraan sendiri seperti kasus pengiriman ternak sapi potong dari Banyuwangi ke RPH Bojongkokosan-Sukabumi menunjukkan bahwa dalam kegiatan transportasinya sendiri, jarak antara Nganjuk ke Sukabumi adalah $1264 \mathrm{~km}$ ditempuh dalam waktu 50 Jam. Dalam kegiatan pengangkutan ternak terakhir ke RPH 
Bambang Winarso: Peran Sarana Angkutan Darat Dalam Upaya Peningkatan Efisiensi Distribusi Ternak ...

Bojongkokosan, berangkat dari Banyuwangi jam 16.00 sore dan tiba di Tulis (Pekalongan) jam 5.00 pagi. Sapi diistirahatkan selama 9 jam. Berangkat dari Tulis jam 14.00 siang dan tiba di Bandung jam 1.00 malam. Kemudian ternak diistirahatkan selama sehari semalam dalam rangka pemulihan kesehatan.

Tabel 1. Pengeluaran biaya operasional dalam pengangkutan ternak sapi potong dari tempat asal ternak ke tempat tujuan di Berbagai Lokasi Penelitian, Thn 2013*

\begin{tabular}{|c|c|c|c|c|c|c|c|c|c|}
\hline \multirow{2}{*}{ No } & \multirow[b]{2}{*}{ Route } & \multirow{2}{*}{$\begin{array}{c}\text { Alat } \\
\text { angkut }\end{array}$} & \multirow{2}{*}{$\begin{array}{l}\text { Nilai } \\
\text { kendaraan } \\
(\mathrm{Rp})\end{array}$} & \multicolumn{6}{|c|}{ Biaya angkutan yang harus dikeluarkan (Rp/trip) $* *$} \\
\hline & & & & 1 & 2 & 3 & 4 & 5 & $\begin{array}{r}\text { Total } \\
\text { Biaya }\end{array}$ \\
\hline 1 & Banyuwangi-Sukabumi & Truk**** & 260000000 & $\mathrm{Bad}$ & 133500 & $\mathrm{Bad}$ & 50000 & Bad & Bad \\
\hline 2 & Banywangi - Purwakarta & Truk**** & 230000000 & Bad & Bad & Bad & Bad & Bad & Bad \\
\hline 3 & Nganjuk - Purwakarta & Truk**** & 240000000 & Bad & 53000 & 300000 & Bad & $\mathrm{Bad}$ & $\mathrm{Bad}$ \\
\hline 4 & Pati - Purwakarta & Truk**** & 250000000 & Bad & Bad & $\mathrm{Bad}$ & $\mathrm{Bad}$ & Bad & Bad \\
\hline 5 & Bojonegoro - Sukabumi & Truk $* * * *$ & 265000000 & Bad & $\mathrm{Bad}$ & $\mathrm{Bad}$ & $\mathrm{Bad}$ & $\mathrm{Bad}$ & Bad \\
\hline 6 & Magetan-Bandung & Truk $* * * *$ & 235000000 & 800000 & 100000 & 300000 & $\mathrm{Bad}$ & $\mathrm{Bad}$ & $\mathrm{Bad}$ \\
\hline 7 & Purwakarta-Bandung & Pick up & 97000000 & 125000 & 15000 & 100000 & 25000 & $\mathrm{Bad}$ & $\mathrm{Bad}$ \\
\hline 8 & Purwakarta - Jakarta & Pick up & 97000000 & 125000 & 12000 & 75000 & 50000 & $\mathrm{Bad}$ & $\mathrm{Bad}$ \\
\hline 9 & Purwakarta-Banten & Pick up & 97000000 & 250000 & 26000 & 150000 & 75000 & $\mathrm{Bad}$ & $\mathrm{Bad}$ \\
\hline 10 & Purwakarta-Bogor & Pick up & 97000000 & 140000 & 40000 & 100000 & 50000 & $\mathrm{Bad}$ & $\mathrm{Bad}$ \\
\hline 11 & Purwakarta-Cianjur & Pick up & 97000000 & 150000 & 20000 & 100000 & 50000 & $\mathrm{Bad}$ & $\mathrm{Bad}$ \\
\hline
\end{tabular}

Keterangan : *) Catatan :1 = biaya bahan bakar 2= Biaya tol 3= Biaya akomodasi supir/kenek 4 = Biaya Pos pemeriksaan ternak/mel 5= Biaya servis, Ganti oli, ganti ban, pajak dan penyusutan mobil (Perkiraan penyusutan berdasarkan Depresiation declining method), **) Jenis Kendaraan truk kecil/engkel; ***) Jenis Kendaraan truk besar/Fuso ; $\quad$ Bad = Belum ada data

Menurut informasi responden bahwa tidak semua jenis biaya yang dikeluarkan selama di perjalanan tidak diketahui, sebab pembagian uang perjalanan ada di masing-masing orang yaitu sopir truk, kenek dan pengantar. Sementara biaya yang diterima oleh pengantar adalah Rp 900.000 dengan perincian 500.000 sebagai uang operasional (makan minum ternak, tip-tip diperjalanan dan biaya surat-surat dan pembelian tiket bis untuk pulang kembali ke Nganjuk). Sedangkan sisanya Rp 400.000 sebagai pesangon pengantar. Sementara realisasi pengeluaran biaya surat-surat ternak adalah sebesar Rp 350.000/truk, makan minum ternak di Tulis sebesar Rp 100.000/truk, tip-tip yang harus dikeluarkan selama perjalanan Rp 50.000, biaya Tol Cileunyi Rp 3.000.

Bagi pebisnis ternak sapi potong yang sekaligus meiliki kendaraan pribadi, maka salah satu kasus menunjukkan bahwa jenis angkutan yang dimiliki oleh responden yakni pickup (Mitshubishi) dengan kapasitas tonase 1,5 ton, apabila untuk membawa ternak dapat memuat 3 ekor untuk ternak sapi besar, sapi kecil dapat memuat 5 ekor dalam memuat ternak ini keadaan terbuka bagian atasnya. Route yang selalu menjadi tujuannya meliputi daerah Bandung, Cianjur, Bogor, Jakarta dan Banten. Besarnya ongkos angkut ternak sapi potong yang harus dikeluarkan tergantung tujuan pengiriman ternak. Untuk pengiriman ternak sapi potong ke Bandung sekali jalan Rp. 550.000, ke Cianjur Rp. 450.000, ke Bogor Rp. 600.000, ke Jakarta Rp. 600.000 sementara ke wilayah Banten Rp. 1.200.000.

Biaya operasional yang dikeluarkan oleh pemilik kendaraan untuk sekali pengiriman ke Bandung diantaranya adalah untuk biaya BBM Rp. 125.000, uang makan Rp. 70.000, surat jalan Rp. 10.000 dan pungutan liar Rp. 50.000. Sedangkan untuk biaya pengeluaran lainnya, yakni ganti oli mesin per bulan Rp. 150.000, ban mobil setiap 10 bulan sekali membeli 2 buah (a Rp.500.000), penggantian kopling 6 bulan sekali Rp. 150.000 dan untuk biaya-biaya montir dalam 1 tahun Rp. 600.000. Bahkan dari pengalaman membawa ternak pernah mengalami hal yang tidak diduga yaitu ternak yang diangkut mati di dalam perjalanan waktu pengiriman ke Cianjur, dan atas inisiatif pengemudi memberikan uang pengganti sebesar Rp. 600.000. Penggantian tersebut sebenarnya diluar perjanjian, akan tetapi lebih kepada pertanggungjawaban daripada pengirim. 
Kasus pemilik lainnya menunjukkan bahwa jenis kendaraan yang dimiliki oleh salah satu responden yakni, Pick Up Mitshibusi bak terbuka dengan kapasitas tonase 1,7 ton. Dalam kegiatan sehari-harinya apabila tidak digunakan mengangkut ternak sapi, mobil digunakan untuk mengangkut produk-produk pertanian. Untuk ternak sapi ukuran kecil dapat terisi 10 ekor dan untuk ukuran besar/dewasa 4 ekor. Route yang ditempuh meliputi daerah Jampang Surade (Sukabumi), Leuwiliang (Bogor) dan untuk yang dekat sekitar lokasi responden.

Tabel 1 menunjukkan bahwa untuk biaya angkut ternak daerah yang jauh Jampang Surade Rp. 150.000, daerah Leuwiliang Rp. 100.000 dan untuk daerah yang dekat sekitar responde Rp. 50.000. Biaya operasional yang disiapkan untuk sekali jalan membeli bahan bakar beserta makan kurang lebih Rp. 200.000 dan untuk pungutan dijalan ke daerah Jampang Surade dan Leuwiliang yang resmi sekitar Rp. 20.000 sedangkan untuk yang tidak resmi Rp. 10.000. Dan biaya yang yang dikeluarkan lainnya untuk kendaraan yakni, untuk penggantian oli dilakukan 1 bulan sekali yakni, Rp. 100.000 dan untuk penggantian ban mobil dilakukan 1 tahun membeli 4 ban dengan harga per satu ban Rp. 400.000 jadi dalam satu tahun biaya untuk ban sebesar Rp. 1.600.000.

\section{a. Alat angkut Truk Besar}

Route yang ditempuh untuk distribusi ternak sapi potong dari daerah sentra produksi ke wilayah sentra konsumen pada dasarnya ditempuh melalui bermacam route dan sarana yang digunakan juga bervariasi. Kasus di Jawa terutama dari Jawa Tengah dan Jawa Timur yang merupakan sentra ternak sapi potong, dalam kegiatan distribusi ternaknya maka sarana transportasi angkutan yang digunakan umumnya truk ukuran besar yang disamping memiliki daya angkut tinggi juga mampu melakukan perjalanan jarak jauh. Tujuan utama adalah sentra-sentra konumen di Jawa Barat seperti Pasar Ternak Ciwareh di Purwakarta, RPH Bandung, RPH Bogor maupun RPH BojongkokosanSukabumi. Bahkan kegiatan pengiriman ternak ke beberapa wilayah sentra konsumen di Jawa Barat tersebut juga datang dari luar Jawa seperti dari Sumatera Selatan dan Lampung.

Digunakannya sarana angkutan type besar tersebut menunjukkan bahwa transaksi-transaksi dalam pemasaran ternak juga dilakukan dalam skala besar (> 15 ekor/trip) dan jarak tempuh yang dilakukan umumnya > $700 \mathrm{~km}$. Sementara sarana angkutan yang digunakan untuk mendukung transaksi-transaksi dalam skala menengah biasanya menggunakan kendaraan skala menengah dan kecil. Sementara kegiatan ditribusinya sendiri juga relative terbatas yaitu antar kabupaten, antar kecamatan atau bahkan desa-desa di sekitar sentra transaksi (pasar) dengan jarak tempuh $<300 \mathrm{~km}$. Dalam pola pemasaran seperti ini sarana angkutan yang digunakan umumnya kendaraan kecil bak terbuka dengan kapasitas angkut maksimal 4 ekor sapi ukuran sedang/trip, sedang untuk sapi ukuran besar hanya mampu mengangkut 2 ekor/trip. Akan tetapi untuk sapi ukuran kecil (pedet sapihan) bisa memuat 8 ekor - 10 ekor/trip. Informasi selengkapnya ditampilkan dalam Tabel 2.

Dalam kegiatan transportasi ternak sapi potong, truk besar merupakan tulang punggung dalam mendukung aktivitas distribusi. Karakteristik truk besar adalah kendaraan truk ukuran besar dengan kapasitas daya angkut sampai dengan 21 ekor ternak sapi ukuran sedang per sekali angkut, dan mampu menempuh jarak jauh. Bagi pedagang ternak sapi potong, sarana kendaraan ini dipandang cukup efisien dalam hal kegiatan angkutan ternak disamping juga juga dapat diandalkan ketersediaannya manakala dibutuhkan. Hasil analisis finansial menunjukkan bahwa usaha angkutan ternak sapi potong dengan menggunakan truk ukuran besar mampu memberikan hasil positip 
Bambang Winarso: Peran Sarana Angkutan Darat Dalam Upaya Peningkatan Efisiensi Distribusi Ternak ...

Tabel 2. Aktivitas pengangkutan ternak sapi potong dari daerah konsumen ke daerah Produsen di Berbagai Lokasi Penelitian, 2013.

\begin{tabular}{lllrrrr}
\hline No & \multicolumn{1}{c}{ Route } & $\begin{array}{c}\text { Alat } \\
\text { angkut }\end{array}$ & $\begin{array}{c}\text { Waktu \& } \\
\text { jarak tempuh } \\
\text { (Jam-km) }\end{array}$ & $\begin{array}{c}\text { Ongkos } \\
\text { sewa alat } \\
\text { angkut } \\
\text { (Rp/trip) }\end{array}$ & $\begin{array}{c}\text { Jum. trnk } \\
\text { terangkut } \\
\text { terakhir } \\
\text { (ekor) }\end{array}$ & Rp/ek/km \\
\hline 1 & Banyuwangi-Sukabumi & Truk** & $50(1264)$ & 3.200 .000 & 14 & 228.571 \\
2 & Banyuwangi - Purwakarta & Truk** & $48(1038)$ & 3.500 .000 & 18 & 194.444 \\
3 & Nganjuk - Purwakarta & Truk** & $16(691)$ & 2.300 .000 & 14 & 164.286 \\
4 & Bojonegoro - Sukabumi & Truk** & $14(961)$ & 3.000 .000 & 15 & 200.000 \\
5 & Pati - Purwakarta & Truk** & $14(767)$ & 2.800 .000 & 15 & 186.667 \\
6 & Purwakarta - Bandung & Pick up & $4(66)$ & 550.000 & 3 & 183.333 \\
7 & Purwakarta - Jakarta & Pick up & $2(117)$ & 450.000 & 3 & 150.000 \\
8 & Purwakarta - Banten & Pick up & $6(230)$ & 1.200 .000 & 3 & 400.000 \\
9 & Purwakarta - Bogor & Pick up & $3(176)$ & 600.000 & 3 & 200.000 \\
10 & Purwakarta - Cianjur & Pick up & $3(130)$ & 600.000 & 3 & 200.000 \\
\hline
\end{tabular}

Keterangan : *) Jenis Kendaraan truk kecil/engkel; trip=sekli jalan

**) Jenis Kendaraan truk besar/Fuso

\section{b. Transportasi Truk Sedang}

Dalam upaya kegiatan proses distribusi pengiriman ternak sapi potong dari wilayah produsen ke wilayah konsumen atau pengiriman ternak sapi potong yang dilakukan antar pedagang, disamping menggunakan alat angkut truk ukuran besar (jenis Fuso), juga menggunakan alat angkutan jenis truk ukuran sedang yang umumnya merk cold Mitsubishi engkel. Sebagai konsekwensi bahwa truk ukuran sedang tersebut kapasitas daya angkut ternak sapi potong tidak sebanyak truk ukuran besar. Dalam satu kali angkut umumnya mampu mengangkut ternak sapi potong sebanyak $10 \mathrm{~s} / \mathrm{d} 14$ ekor ukuran sedang. Digunakannya alat angkut jenis truk ukuran sedang, disamping ongkos sewa lebih murah, maka daya jangkau juga fleksibel artinya bisa digunakan dalam jarak jauh maupun jarak dekat.

Namun demikian penggunaan truk ukuran sedang juga banyak digunakan untuk mengangkut ternak sapi potong dalam jarak jauh. Kasus angkutan ternak sapi potong dari Tuban ke Jakarta, Bogor dan Bandung maupun dari daerah-daerah sentra ternak sapi potong di Jawa Timur ke Jawa Barat juga sering menggunakan truk ukuran sedang. Pengunaan truk ukuran sedang biasanya digunakan untuk mengangkut ternak sapi ukuran kecil sampai sedang yang biasanya merupakan ternak yang masih diperdagangkan dan bukan sapi ukuran besar yang biasanya untuk konsumsi RPH.

\section{c. Transportasi Mobil Kecil Bak terbuka}

Mobil bak terbuka merupakan sarana angkutan ternak maupun ternak yang umumnya digunakan untuk menempuh jarak pendek, baik digunakan untuk mengangkut ternak hidup maupun hasil ternak (daging hasil pemotongan). Karakteristik mobil bak terbuka umumnya mobil ukuran kecil dengan merk Mitsubishi L-300, daya tamping ternak 4 s/d 10 ekor ternak sapi ukuran kecil sampai sedang. Jarak tempuh umumnya $<100 \mathrm{~km}$, banyak digunakan untuk mengantar ternak sapi dari peternak yang akan dijual ke pasar atau sebaliknya.

Jenis kendaraan Pick Up Mitshibusi bak terbuka dengan kapasitas tonase 1,7 ton merupakan kendaraan angkut yang digunakan dalam mendukung transportasi ternak sapi jarak dekat. Secara umum kegiatan mobil tersebut sehari-harinya apabila tidak digunakan mengangkut ternak sapi, mobil digunakan untuk mengangkut produk-produk pertanian. Daya tampung untuk mengangkut ternak sapi ukuran kecil dapat terisi 10 ekor dan untuk ukuran besar/dewasa 4 ekor. Route yang ditempuh tidak terlalu jauh sehingga biaya angkut ternak yang dikenakan juga tidak terlalu tinggi berkisar antara Rp $50.000 \mathrm{~s} / \mathrm{d} 200.000$ per trip. 
Jurnal Penelitian Pertanian Terapan

\section{Transportasi mobil Truk Refrigerator}

Salah satu perusahaan pengangkut daging dari Surabaya ke Jakarta dengan menggunakan sarana kendaraan truk yang dilengkapi dengan box pendingin (refrigerator) yang berhasil dikunjungi adalah PT Suryajaya. PT Suryajaya dalam upaya melakukan kegiatan transportasi daging beku dengan menggunakan refrigerator sebagian kendaraannya adalah menyewa. Daging diangkut dari Surabaya ke Jakarta. Volume angkut rata-rata kurang dari 5 ton/trip dengan ongkos sewa sebesar Rp 3 juta/trip. Dari ongkos sewa yang diterima tersebut biaya operasional yang harus dikeluarkan sebesar Rp 1,5 juta yaitu untuk sapir, bahan bakar dan biaya lainnya. Selain mengangkut daging dari Surabaya ke Jakarta, maka arah sebaliknya dari Jakarta ke Surabaya mobil membawa ikan segar yang juga membutuhkan box pendingin. Jadwal pengangkutannya sendiri tidak menentu tergantung order permintaan dan operasional PT Suryajaya sendiri saat penelitian ini dilakukan sedang mengalami kemunduran omzet sehubungan dengan harga ternak yang terus meningkat.

Hasil analisis komparatif yang dilakukan oleh Ilham dkk (2013) terhadap kegiatan transportasi pengangkutan daging dengan menggunakan berbagai alat angkut menunjukkan bahwa sistem pengangkutan yang paling efisien adalah menggunakan kereta api, dimana dengan ongkos angkut sebesar Rp 1,6 juta/theus maka besarnya biaya angkut daging sebesar Rp 80/kg. Sementara sistem angkutan dengan menggunakan pesawat merupakan sarana transportasi yang paling mahal apabila digunakan untuk mengangkut daging. Dengan tariff Rp 8400/kg dan batasan angkutan sebanyak 250 $\mathrm{kg} /$ paket merupakan ongkos yang sangat tinggi. Akan tetapi sistim angkutan melalui pesawat terbang mempunyai keunggulan dari segi waktu, jarak tempuh dari kota asal barang sampai dengan di kota tujuan hanya membutuhkan waktu 1,5 jam.

Disisi lain alat tranportasi darat khususnya kendaraan roda empat atau lebih, untuk kegiatan pengangkutan ternak maupun hasil ternak maka pengangkutan daging dengan menggunakan kendaraan berpendingin (refrigerator) lebih efisien jika dibandingkan dengan mengankut ternak hidup menggunakan truk besar. Kapasitas yang besar dari truk besar belum bisa menjamin lebih efisien, analisa menunjukkan bahwa membawa ternak hidup dengan menggunakan truk besar dengan kapasitas 14 ekor sapi ukuran $450 \mathrm{~kg} / \mathrm{kg}$ ongkosnya jauh lebih besar jika dibandingkan dengan kendaraan L-300 yang mengangkut daging. Besarnya ongkos angkut ternak hidup jatuhnya adalah sebesar Rp 1.010/kg setara daging, sedangkan mengangkut daging dengan menggunakan kendaraan berfasilitas pendingin hanya Rp 600/kg.

Hal ini menunjukkan bahwa transportasi daging (hasil ternak) jauh lebih efisien jika dibandingkan dengan mengangkut sapi hidup, terutama kegiatan pengangkutan dengan menggunakan sistem angkutan darat, baik menggunakan kendaraan berpendingin (Refrigerator) maupun dengan kereta api yang memiliki fasilitas refer container. Dari keadaan yang demikian, maka untuk kedepan perlu dipikirkan kiranya bahwa sistem angkutan daging segar/beku perlu mendapat perhatian. Dengan difokuskan pada sistem pengangkutan daging dari daerah produsen ke daerah konsumen tentu memiliki implikasi positip maupun negatip. Dari sisi positif bahwa disamping lebih efisien, maka penciptaan lapangan kerja dan lapangan usaha di daerah produsen akan lebih terbuka. Selain itu dampak positif lainnya bahwa lingkungan di daerah konsumen akan jauh lebih baik terutama terbebas dari adanya pencemaran limbah buangan hasil pemotongan ternak. Dari sisi negatip tentu berdampak terhadap hilangnya beberapa peluang bisnis komoditas asal ternak seperti kegiatan RPH dan sejenisnya di wilayah konsumen. Sebaliknya di daerah produsen tentu dihadapkan pada masalah pencemaran lingkungan yang semakin bertambah. 
Bambang Winarso: Peran Sarana Angkutan Darat Dalam Upaya Peningkatan Efisiensi Distribusi Ternak ...

\section{KESIMPULAN}

Dalam hal angkutan darat fasilitas angkutan kereta api sebenarnya merupakan sarana angkutan darat yang sangat prospektip disamping cepat, aman, tepat waktu, sarana prasarana tersedia juga murah. Akan tetapi pemanfaatan sarana angkutan kereta api terutama untuk sapi hidup saat ini memang tidak ada. Hal ini sejalan dengan kebijakan manajemen PT KAI (Kereta Api Indonesia) bahwa PT KAI tidak melayani pengangkutan ternak sapi hidup, kecuali hasil ternak (daging) yang dittangani dengan sistem kontainer beku (river kontainer). Secara finansial ongkos angkut dengan menggunakan kereta api termasuk murah, besaran biaya yang dikenakan dari Surabaya s/d Jakarta per TUE (20 ton) Rp.1.600.000.

Jenis angkutan darat lainnya yang banyak dimanfaatkan untuk pengangkutan ternak sapi terutama sapi hidup adalah truk. Sarana ini merupakan tulang punggung dalam aktivitas pengangkutan ternak sapi hidup. Hal ini disebabkan karena fasilitasnya tersedia dan mudah diakses oleh pengguna, dapat menjangkau sapai ke hampir semua lokasi tujuan pengiriman. Walaupun secara financial besarnya sewa truk relative mahal (Rp 2.532/km s/d Rp 5.217/km) kenyataan menunjukkan bahwa dalam kegiatan tranportasi ternak sapi terutama sapi hidup, penggunaan sarana ini sangat dominan.

Dari pola perdagangan sapi potong yang terjadi selama ini dilakukan, maka ada indikasi bahwa sangat memungkinkan untuk mengganti dari mendatangkan sapi hidup menjadi mendatangkan karkas beku. Disamping lebih efisien maka kegiatan tersebut akan lebih mampu menciptakan lapangan kerja dan lapangan usaha di wilayah sentra ternak.

\section{DAFTAR PUSTAKA}

Abbas, S.A. 2006. Manajemen Transportasi.Rajawali Press, Jakarta.

Abubakar, I. 2011. Moda Transportasi. http://id.wikibooks.org/wiki/moda Transportasi/ : Diunduh 7 juli 2012-07-07

Ilham, N. 2001. Prospek Pasar dan Sistem Tataniaga Ternak dan Daging Sapi di Nusa Tenggara Barat. Wartazoa, Vol 11 (2): 32-43

Ilham, N. dan Y. Yusdja. 2004. Sistem Transportasi Perdagangan Ternak Sapi dan Implikasi Kebijakan di Indoneisa. Analisis Kebijakan Pertanian, Vol. 2 (1).

Ilham, N., E. Basuno, B. Winarso, A.K. Zakaria, T. Nurasa dan T.S. Wahyudi. 2013. Kajian Efisiensi Moda Transportasi Ternak dan Daging Sapi Dalam Mendukung Program Swasembada Daging Sapi. Pusat Sosial Ekonomi dan Kebijakan Pertanian. Badan Litbang Pertanian.

Jurnal Kajian Lemhannas RI Edisi 14, 2012 ; Pengembangan Sistem Transportasi Nasional guna Mempercepat dan Memperluas Pembangunan Ekonomi dalam Rangka Ketahanan Nasional

Puslitbang Peternakan. 2011. Kinerja Budidaya dan Pemasaran Sapi dan Kerbau dalam Upaya Pencapaian PSDSK-2014. Kegiatan Kemitraan antara Badan Penelitian dan Pengembangan Pertanian dengan Pusat Penelitian dan Pengembangan Peternakan, Bogor.

Peraturan Pemerintah No 8 Tahun 2011 tentang Angkutan Multimoda

Peraturan Pemerintah No 18/2011 tentang Multimoda (Menkumham, 2011). 
Jurnal Penelitian Pertanian Terapan

The Asia Foundation, 2008; Biaya Transportasi Barang Angkutan, Regulasi, dan pungutan Jalan di Indonesia; Kerangka Hukum Biaya Transportasi

Undang-undang No 23/2007 tentang Perkeretaapian

Undang-undang No 22/2009 tentang Lalu Lintas dan Angkutan Jalan

Wikipedia.2011. Efisiensi Transportasi. http://id.wikipedia.org/wiki/Efisiensi_transportasi: Diunduh 7 juli 2012-07-07

Winarso, B : Pola Transportasi Ternak dan Hasil Ternak Sapi Potong di Indonesia; Paper telah diseminarkan di Universitas Brawijaya Brawijaya , 2014 